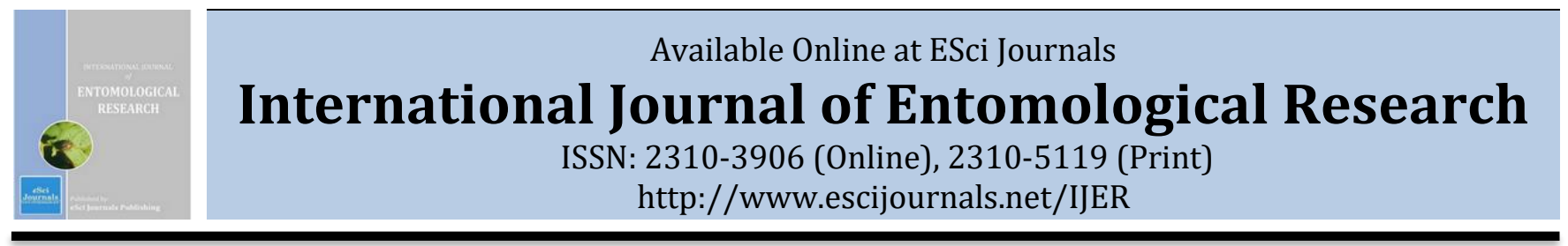

\title{
MICROHABITAT CHARACTERISTICS OF MYOpopone castanea (HYMENOPTERA: FORMICIDAE) IN OIL PALM PLANTATION
}

aWidihastuty, bMaryani C. Tobing*, bMarheni, cRetna A. Kuswardani

${ }^{a}$ Faculty of Agriculture, Universitas Sumatera Utara, Padang Bulan, Medan 20155, Indonesia.

b Program Study of Agrotechnology, Faculty of Agriculture, Universitas Sumatera Utara, Medan 20155, Indonesia.

c Program Study of Agrotechnology, Faculty of Agriculture, Universitas Medan Area, Medan, Indonesia.

*Corresponding Author Email: cyccutobing@gmail.com

\section{A B S T R A C T}

Ants are social insects which widespread and play many important roles in an ecosystem. Myopopone castanea ants are a predator for the pre-adult stage of pest Oryctes rhinoceros which is one of the important pests in oil palm plantations. At the oil palm plantations, M. castanea and pre-mature stadia from pests O. rhinoceros live on decaying palm oil stems. This study aimed to explore the presence and the microhabitat characteristics of $M$. castanea ant in oil palm plantation so that mass rearing of $M$. castanea ants can be carried out in the laboratory to support the natural enemy augmentation program in biological control of 0 . rhinoceros pest. The exploration of ant nests was carried out in two plantation locations: smallholder oil palm plantations in Tanah Merah sub-district, Binjai Selatan Subdistrict, Binjai and PTPN 2 and PTPN 4 in Deli Serdang and Serdang Bedagai districts, North Sumatra Province. The results showed that the colonies of M. castanea in both of plantations vary greatly in the size of the number and stage of the ant development stage. Average of abiotic factors in the microhabitat of $M$. castanea ants in PTPN plantation $\left(\mathrm{t}=29.7^{\circ} \mathrm{C}, \mathrm{Rh}=70 \%, \mathrm{pH}=6.03\right.$ and $\mathrm{C} / \mathrm{N}$ ratio $=66.18 \%$ ), while for smallholder plantation $\left(\mathrm{t}=29.1{ }^{\circ} \mathrm{C}, \mathrm{Rh}=70.9 \%, \mathrm{pH}=6.39\right.$ and $\mathrm{C} / \mathrm{N}$ ratio $\left.=69.01 \%\right)$. A suitable abiotic environment will support life and mass rearing of $M$. castanea ant colonies.

Keywords: Microhabitat, abiotic environment, Myopopone castanea, oil palm, mass rearing.

\section{INTRODUCTION}

Ants are social insects which widespread, high diversity and adaptability, therefore their presence can be found in all habitats. The presence of ants in an ecosystem can indicate the condition of an ecosystem whether it is good or bad and provide an overview of the existence of other organisms within an ecosystem (Tiede et al., 2017; El Bokl et al., 2015). In an ecosystem, ants occupy various ecological niches and play an important role such as acting as pollinators, predators for herbivorous insects and scavengers. The role of ants as predators in an ecosystem has been widely reported (Yamazaki, 2010; Dassou et al., 2015; Oliveira et al., 2012). Various species of ants are widely used as biological agents for the pest control in the plantation crops, such as weaver ants (Oecophylla smaragdina) that can prey on nettle caterpillars (Setora nitens) at the high level of predation reached 83\% (Falahudin, 2013; Nurdiansyah et al., 2016).
Dolichoderus thoracicus, able to suppress the attack of Helopeltis sp on cocoa plantations in Sulawesi (Anshary and Pasaru, 2008). Habitat and microhabitats and environmental factors influence the presence of predatory ants. Ants were a sensitive organism to the alteration within their environment includes organisms that are very sensitive to changes that occur in their environment (Latumahina et al., 2015; Luke et al., 2014).

Ants Myopopone castanea (Hymenoptera: Formicidae) is an ant from the Amblyoponinae family, most of these ants are predatory ants (Ito, 2010). In Indonesia, these ants are the predator of Oryctes rhinoceros (Coleoptera: Scarabaediae) pest which is one of the essential pests in oil palm plantations (Junaedi et al., 2014; Marheni, 2012; Widihastuty et al., 2018). These ants attacked the premature stage of $O$. rhinoceros (larvae and pupae). $M$. castanea ants are widely found in forests, temperate regions, or in the tropics. In hot regions, these ants live 
in the soil (Wilson, 1971). In the palm plantations, $M$. castanea ants can be found on fallen palm stems and have decayed due to the aged or because of stem rot. 0 . rhinoceros larvae on the palm plantations usually also lived on the decayed palm trunks and in a pile of organic. The similarity of the living niche between $M$. castanea and $O$. rhinoceros larvae provided a great opportunity to utilize these predator ants as the potential biological agent for 0 . rhinoceros pest through natural enemy augmentation program. The augmentation of the natural enemy was an effort to multiply increase and enlarge the natural enemy population which was initially carried out in the laboratory through mass rearing. To be able to do mass rearing of a biological agent, it was necessary to understand the various ecological aspects of the natural enemy. Information about the ecological aspects of the $M$. castanea ant, especially those that encompassed the microhabitat of ants in the palm plantations did not exist, yet. Therefore, it needs to explore some information about the ecological aspects of ants $M$. castanea in the field, especially about the microhabitat of ants in the oil palm plantations, hence it can be applied to the mass rearing of these ants in the laboratory.

\section{MATERIAL AND METHODS}

The study was conducted from February to July 2018 with the exploration methods in the palm plantations that owned by PTPN 2 and PTPN 4 (PTPN is a company which engages in the business of agro-industry) in Deli Serdang Regency and Serdang Bedagai Regency as well as in the smallholders' palm plantations in the area of Tanah Merah sub-district, Binjai Selatan District, Binjai, North Sumatra Province.

The Ants Nest Exploration: Seeking the M. castanea ant colonies was carried out 20 times, 10 times in the smallholders' palm plantations and 10 times in the PTPN's. M. castanea ants in the palm plantations were living on the fallen and decayed trunks and stumps of the palm stems due to the aged or die of stem rot. The decayed palm stem or stump cut into pieces and chopped up to find ant colonies (figure 1) if the ant colonies found then a thermometer, humidity (Hygrometer) and $\mathrm{pH}(\mathrm{pH}$ meter) were plunged into the ant nests to measure the abiotic environment in ant nests. After the abiotic factor measurement was recorded and completed, the ants were compiled and put into a plastic box included the pieces of palm oil stem where the ant nests placed and taken to the USU Faculty of Agriculture's plant pest laboratory Universitas Sumatera Utara for mass rearing. The pieces of palm oil where the ant nest was then analyzed the $\mathrm{C} / \mathrm{N}$ ratio in the laboratory of the Assessment Institute of Agricultural (AIAT) Medan North of Sumatera and the laboratory of PT Nusa Pusaka Kencana Asian Agri, Medan.
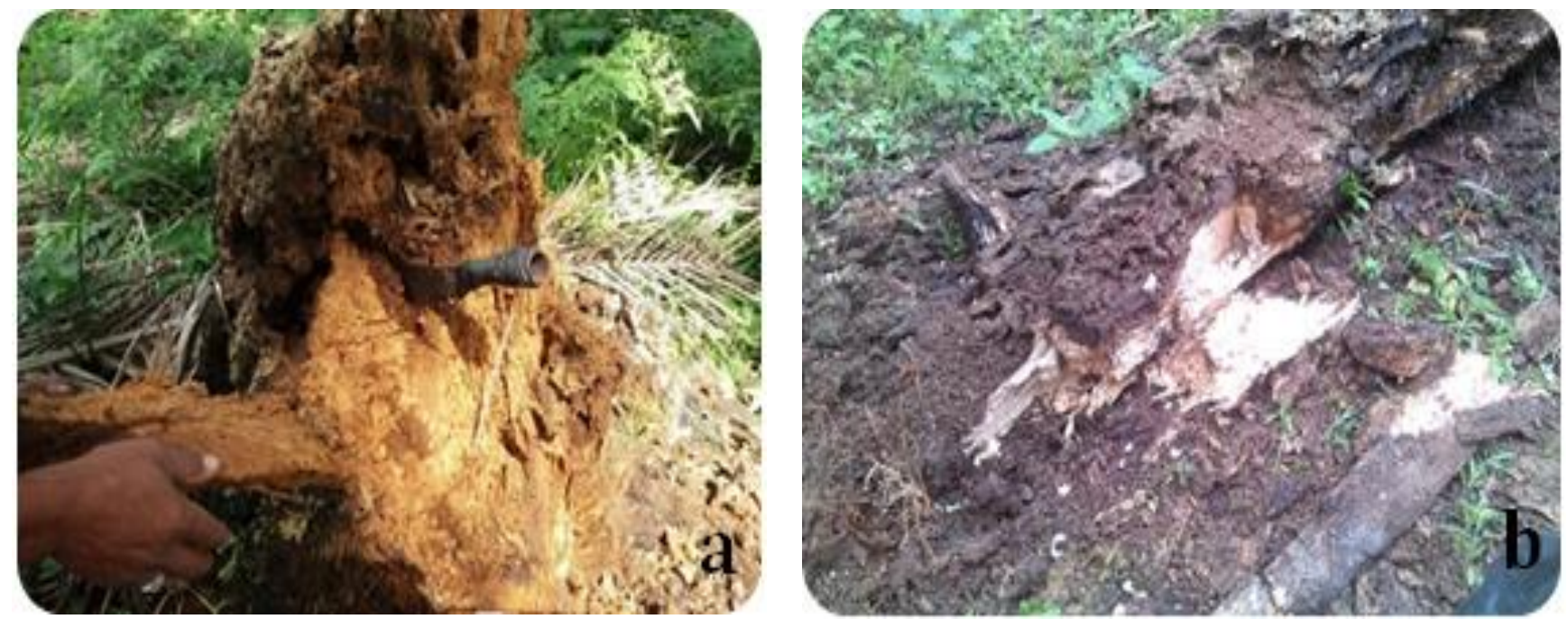

Figure 1. The Ant nests of Myopopone castanea in the palm plantation. $a=$ ant nest in oil palm stump; $\mathrm{b}=$ ant nest in fallen palm oil stems. 


\section{RESULTS AND DISCUSSION}

Colonies of $\boldsymbol{M}$. castanea: The results of the exploration M. castanea colonies ants carried out in both oil palm plantation locations, the number of ant colony members found significantly varied (table 1 ).

The stages of ant development such are eggs, larvae, pupae and imago are not always present in every colony found. Some colonies only have pupae stadia and worker ants, or just the larvae and worker ants. Very rarely in one colony do we get all groups of ant development stages. In the smallholder oil palm plantations, there were ant colonies found where all stages of ant development were in the colony, whereas those in the PTPN plantation were not found in complete colonies.
Based on observations in the laboratory it was suspected that colonies of $M$. castanea ants belonged to the ant group which had queen dealate, namely female ants married to male ants and laid eggs, and worker ants that could reproduce (gamergates). According to (Peeters and Fisher, 2016), more than 100 poneroid species (subfamily Amblyoponinae, Ponerinae and ectatommine ants show gamergates events. From table 1, it can also be seen that ant colonies that do not have queens actually number the colony members were fewer than the colonies who had the real queen, (Monnin and Peeters, 2008) stated that ant colonies that did not have actual queens were generally less colonies than ant colonies who had actual queens.

Table 1. M. castanea colonies in oil palm plantation.

\begin{tabular}{|c|c|c|c|c|c|c|c|c|c|c|}
\hline \multirow[t]{2}{*}{ Colonies } & \multicolumn{5}{|c|}{ Smallholder Plantation } & \multicolumn{5}{|c|}{ PTPN Plantations } \\
\hline & Eggs & Larvae & Pupae & Ants & Note & Eggs & Larvae & Pupae & Ants & Note \\
\hline 1 & - & 34 & 16 & 23 & & - & 58 & - & 85 & \\
\hline 2 & 321 & 111 & 15 & 132 & $\begin{array}{l}\text { Male }=3 \\
\text { Female }=4 \\
\text { Queen }=1\end{array}$ & - & 79 & - & 117 & \\
\hline 3 & - & 44 & 16 & 59 & & - & 36 & - & 62 & \\
\hline 4 & - & 103 & 5 & 69 & & - & 128 & 23 & 79 & \\
\hline 5 & - & 145 & 5 & 83 & & - & 58 & 62 & 53 & \\
\hline 6 & - & 24 & 15 & 96 & $\begin{array}{l}\text { Male }=4 \\
\text { Female }=6\end{array}$ & - & 86 & 45 & 94 & $\begin{array}{l}\text { Male }=3, \\
\text { Female }=2\end{array}$ \\
\hline 7 & - & 12 & 77 & 78 & & - & 36 & 43 & 38 & $\begin{array}{l}\text { Male }=2, \\
\text { Female }=1\end{array}$ \\
\hline 8 & 279 & 53 & 9 & 102 & $\begin{array}{l}\text { Male = } 7, \\
\text { Female = } \\
10 \\
\text { Queen = } 1\end{array}$ & - & 126 & 27 & 82 & \\
\hline 9 & - & 52 & 15 & 60 & $\begin{array}{l}\text { Male }=2, \\
\text { Female }=5\end{array}$ & - & 35 & 18 & 44 & $\begin{array}{l}\text { Male }=7, \\
\text { Female }=4\end{array}$ \\
\hline 10 & - & 65 & 10 & 73 & $\begin{array}{l}\text { Male }=6 \\
\text { Female }=4\end{array}$ & - & 20 & - & 36 & \\
\hline
\end{tabular}

Based on observations in the laboratory, $M$ castanea ants include nocturnal insects. Worker ants begin to actively exit from the logs where they nest around late in the afternoon, and so do female and male ants actively fly towards dusk. Female ants who have married and become queens will take off their wings. Some ant species are classified as nocturnal insects, such as Camponotus irritans ants, Camponotus ligniperda (Menzi, 1987). Myrmecia pyriformis ants studied by (Reid et al., 2013; Raderschall et al., 2016) also include ants that are nocturnal.

Microhabitat of $\boldsymbol{M}$. castanea: The result of the study showed that average temperature, humidity, pH and C / N ratios found during exploration of ant nests in smallholder oil palm plantations and in PTPN plantation was described in Table 2 . The abiotic environment found in the $M$. castanea ant nests on smallholder plantations and PTPN plantations was not significantly different. It caused by the age range of plants in the PTPN plantation and in the smallholders' palm plantations was almost similar, ranging from 15-20 years. The palm plantations between the ages of 15-20 years canopy plants have covered each other so that the atmosphere in the plantation environment became shadier. (Chen and Robinson, 2014) explained that nests were larger in shadier areas where the thermal environment was colder and more stable compared to open areas. 
Table 2. Average of abiotic environment of ant nest Myopopone castanea in oil palm plantation.

\begin{tabular}{lll}
\hline Indicator (Average) & Smallholder Plantation & PTPN Plantation \\
\hline Temperature $\left({ }^{\circ} \mathrm{C}\right)$ & 29,1 & 29,7 \\
Humidity $(\%)$ & 70,9 & 70,0 \\
pH & 6,39 & 6,03 \\
C/N Ratio (\%) & 69,01 & 66,18 \\
\hline
\end{tabular}

Temperature is an abiotic factor that is very influential in insect life (Kaspari et al., 2015; Sorvari et al., 2011). The temperature range obtained in the exploration of the $M$. castanea ant nest is in the optimal temperature range for living. The range of environmental temperature during the exploration of the plantation was between $29^{\circ} \mathrm{C}$ $31^{\circ} \mathrm{C}$. The temperature range was at the optimal range that needed by the insect for its life. (Tiede et al., 2017) explained that the higher elevation of ant habitat, then the more abundant the ants will decrease. The increase of habitat elevation was related to a decrease in the ambient temperature. In an ecosystem, the temperature was able to regulate the growth and the deployment of animals that live in it (Aneni et al., 2014; Cardoso and Schoereder, 2014; Wang et al., 2001). Interactions among various organisms in an ecosystem can be influenced by the regulation of the abiotic factors of the ecosystem (Kersch and Fonseca, 2005).

Air humidity affected the lives of insects directly or

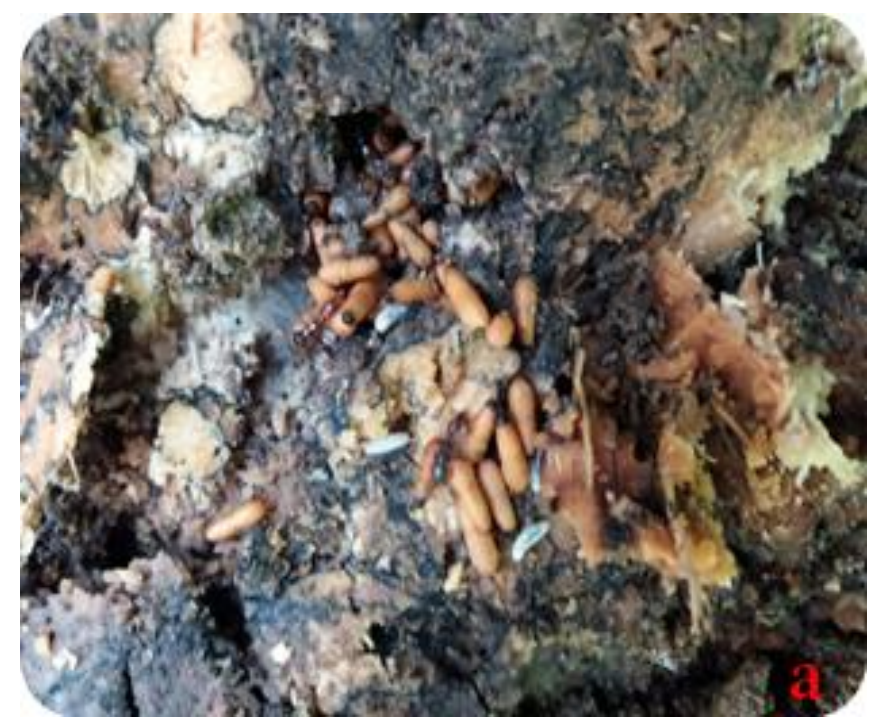

Figure 2 . The colonies of $M$. castanea ants, $\mathrm{a}=$ colonies in the rotten $\log , \mathrm{b}=$ colonies in the soil.
The results of the $\mathrm{pH}$ measurements in the exploration of ant nests in PTPN plantations were on average 6.03 and for the smallholders' plantations, the average $\mathrm{pH}$ was 6.39. The measurement results for the two plantations showed an unreal impact. In the weathering indirectly. The results showed that the average micro humidity of $M$. castanea ants habitat found in PTPN's palm plantations was $70.0 \%$ and $70.9 \%$ for the smallholders' palm plantations. The result showed that the differences in humidity between the two plantations were not significant. The ant nests found during the exploration process in the two plantations were mostly found in the trunks of the palm trees whose trunks look slightly wet (moist), and the ants usually found in the bottom of the fallen palm trunk, there were even ant colonies of $M$. castanea found in the soil (figure 2). M. castanea ants like a moist place to make their nests (Wilson, 1971). Temperature and humidity factors were factors that significantly affected the ant life and activity. It was observed by (Ronque et al., 2018) on Camponotus renggeri ants and Camponotus rufipes which live in the Brazilian savannah area. These ants were also found alive and make nests on decaying logs.

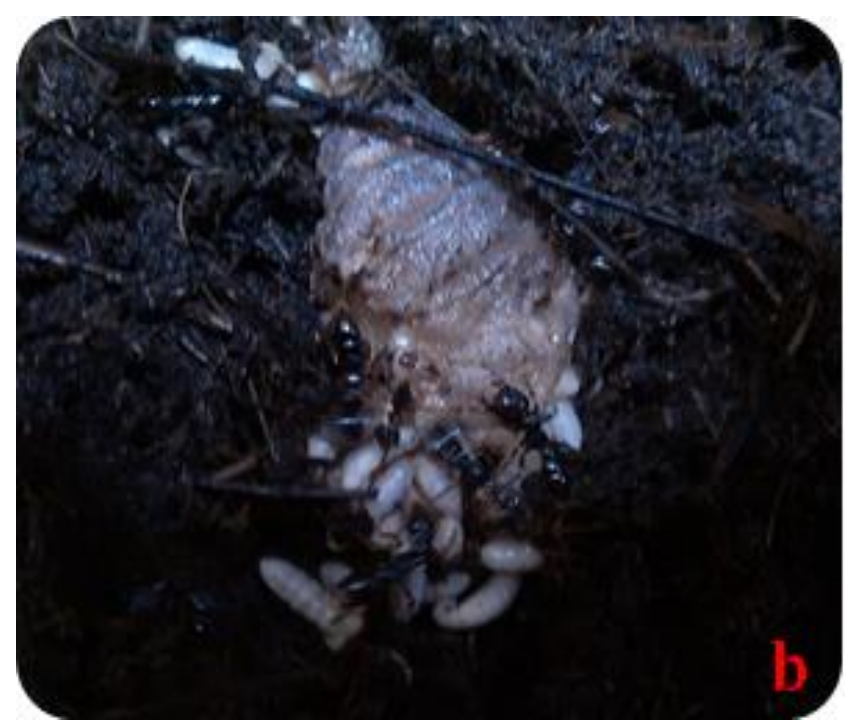

process of palm stems, microorganisms such as fungi played an important role in the destruction of lignin and cellulose. The result of (Fadzilah et al., 2017) research using fungi such as Trametes versicolor and Schizophyllum commune was able to accelerate the 
decomposition process of the palm stems. In order to carry out this decomposition process, these fungi preferred the $\mathrm{pH}$ in a neutral range. P. crisosporium mushroom which was a fungus that played an important role in the wood weathering process preferred the 4-7 pH range as the place of life (Fadilah et al., 2008).

The decomposition speed of organic material was indicated by the changes in the $\mathrm{C} / \mathrm{N}$ ratio. The average of $\mathrm{C} / \mathrm{N}$ ratio obtained from the smallholders' palm plantations was $69.01 \%$ and from the PTPN plantations was $66.18 \%$ (table 2). These results indicated that there were no significant differences between the two plantations. The $\mathrm{C} / \mathrm{N}$ ratio value showed that the decomposition process of the palm stem was incomplete, still many woody parts. The palm stem consisted chiefly of lignin and cellulose such as wood. The chemical content of palm tree was cellulose which ranged from $20-40 \%$, lignin 23-52\%; and other elements (Shibata et al., 2008; Hermawan et al., 2014; Ridwansyah et al., 2007). Decomposition of cellulose into simpler compounds involved many roles of enzymes and microorganisms (Fadzilah et al., 2017; Fadilah et al., 2008). Most possibly, the process of cellulose-decomposing into simpler sugar compounds invited ants to make nests in the decaying logs. Ants needed this sugar for their life. For the ants whose arboreal microhabitat, we often find ant colonies symbiotic with aphids, where they can provide the honeydew needed by ants for their lives. The low $\mathrm{C} / \mathrm{N}$ ratio indicated an advanced weathering process and impact on the cellulose degradation and decreasing the sugar compounds needed by ants.

\section{CONCLUSION}

Colonies of $M$. castanea ants in oil palm plantations vary greatly in the size of the number and stage of the ant development stage. The average abiotic factor in the microhabitat of $M$. castanea ants in PTPN plantations was the temperature $=29.7^{\circ} \mathrm{C}$, the humidity $=70 \%, \mathrm{pH}=$ 6.03 and $\mathrm{C} / \mathrm{N}$ ratio $=66.18 \%$, and the average abiotic factor for smallholders' plantations was $29.1^{\circ} \mathrm{C}$, the humidity $=70.9, \mathrm{pH}=6.39$ and $\mathrm{C} / \mathrm{N}$ ratio $=69.01 \%$. The appropriate abiotic environment will support life and mass multiplication of $M$. castanea ant colonies.

\section{ACKNOWLEDGEMENT}

This research was funded by the Ministry of Riset Teknologi dan Pendidikan Tinggi with grant number 011 / P3M.05 / 2018.

\section{REFERENCES}

Aneni, T. I., C. I. Aisagbonhi, B. N. Iloba, V. C. Adaigbe and
C. O. Ogbebor. 2014. Influence of Weather Factors on Seasonal Population Dynamics of Coelaenomenodera elaeidis (Coleoptera: Chrysomelidae) and Its Natural Enemies in NIFOR, Nigeria. American Journal of Plant Sciences, 05: 42-47. https://doi.org/10.4236/ajps.2014.51007

Anshary, A. and F. Pasaru. 2008. Teknik perbanyakan dan aplikasi predator Dolichoderus thoracicus (Smith)(Hymenoptera: Formicidae) untuk pengendalian penggerek buah kakao Conopomorpha cramerella (Snellen) di perkebunan rakyat. Agroland: Jurnal Ilmu-ilmu Pertanian, 15.

Cardoso, D. C. and J. H. Schoereder. 2014. Biotic and Abiotic Factors Shaping Ant (Hymenoptera: Formicidae) Assemblages in Brazilian Coastal Sand Dunes: The Case of Restinga in Santa Catarina. Florida Entomologist, 97: 1443-50. https://doi.org/10.1653/024.097.0419

Chen, Y.-H. and E. J. H. Robinson. 2014. The Relationship between Canopy Cover and Colony Size of the Wood Ant Formica lugubris - Implications for the Thermal Effects on a Keystone Ant Species. PLoS ONE, 9: e116113. https://doi.org/10.1371/journal.pone.0116113

Dassou, A. G., D. Carval, S. Dépigny, G. Fansi and P. Tixier. 2015. Ant abundance and Cosmopolites sordidus damage in plantain fields as affected by intercropping. Biological Control, 81: 51-57. https://doi.org/10.1016/j.biocontrol.2014.11.008

El Bokl, M. M., F. M. Semida, M. S. Abdel-Dayem and E. I. El Surtasi. 2015. Ant (Hymenoptera: Formicidae) Diversity And Bioindicators In The Lands With Different Anthropogenic Activities In New Damietta, Egypt. International Journal of Entomological Research, 3: 35-46.

Fadilah, S. D., E. K. Artati and A. J. E. Jumari. 2008. Biodelignifikasi batang jagung dengan jamur pelapuk putih Phanerochaete chrysosporium. Ekuilibrium, 1: 1-11.

Fadzilah, K., H. Saini and M. Atong. 2017. Physicochemical Characteristics of Oil Palm Frond (OPF) Composting with Fungal Inoculants. Pertanika Journal of Tropical Agricultural Science, 40.

Falahudin, I. 2013. Diversitas Semut Arboreal (Hymenoptera: Formicidae) Dan Potensinya 
Sebagai Pengendali Ulat Api (Lepidoptera: Limacodidae) Pada Tanaman Kelapa Sawit, Perpustakaan Universitas Andalas.

Hermawan, A., F. Diba, Y. Mariani and D. Setyawati. 2014. Sifat Kimia Batang Kelapa Sawit (Elaeis guinensis Jacq) Berdasarkan Letak Ketinggian Dan Kedalaman Batang Chemical Properties of Oil Palm Trunk (Elaeis guinensis Jacq) Based on Height and Depth of Trunk. Jurnal Hutan Lestari, 2.

Ito, F. 2010. Notes on the biology of the Oriental amblyoponine ant Myopopone castanea: Queenworker dimorphism, worker polymorphism and larval hemolymph feeding by workers (Hymenoptera: Formicidae). Entomological Science, 13: 199-204.

https://doi.org/10.1111/i.14798298.2010.00384.X

Junaedi, D., D. Bakti and F. Zahara. 2014. Daya Predasi Myopopone castaneae (Hymenoptera: Formicidae) terhadap Larva Oryctes rhinoceros L.(Coleoptera: Scarabaidae) di Laboratorium The predation of Myopopone castaneae (Hymenoptera: Formicidae) to larvae of Oryctes rhinoceros L.(Coleoptera: Scar. Agroekoteknologi, 3.

Kaspari, M., N. A. Clay, J. Lucas, S. P. Yanoviak and A. Kay. 2015. Thermal adaptation generates a diversity of thermal limits in a rainforest ant community. Global Change Biology, 21: 1092-102. https://doi.org/10.1111/gcb.12750

Kersch, M. F. and C. R. Fonseca. 2005. Abiotic Factors and the Conditional Outcome of an Ant-Plant Mutualism. Ecology, 86: 2117-26. https://doi.org/10.1890/04-1916

Latumahina, F., M. Musyafa, S. Sumardi and N. S. Putra. 2015. Respon Semut Terhadap Kerusakan Antropogenik Dalam Hutan Lindung Sirimau Ambon (Ants Response to Damage Anthropogenic in Sirimau Forest Ambon). Jurnal Manusia dan Lingkungan, 22: 169. https://doi.org/10.22146/iml.18739

Luke, S. H., T. M. Fayle, E. P, E. C. Turner and R. G. Davies. 2014. Functional structure of ant and termite assemblages in old growth forest, logged forest and oil palm plantation in Malaysian Borneo. Biodiversity and Conservation, 23. https://doi.org/10.1007/s10531-014-0750-2

Marheni. 2012. Karakteristik Ekologi dan Biologi Orytes rhinoceros pada Pertanaman Sawit di Sumatera Utara, Disertasi, Universitas Gadjah Mada, Yogyakarta.

Menzi, U. 1987. Visual adaptation in nocturnal and diurnal ants. Journal of Comparative Physiology A, 160: 11-21. https://doi.org/10.1007/bf00613437

Monnin, T. and C. Peeters. 2008. How many gamergates is an ant queen worth? Naturwissenschaften, 95: 109-16.

Nurdiansyah, F., L. H. Denmead, Y. Clough, K. Wiegand and T. Tscharntke. 2016. Biological control in Indonesian oil palm potentially enhanced by landscape context. Agriculture, Ecosystems \& Environment, 232: 141-49.

https://doi.org/10.1016/j.agee.2016.08.006

Oliveira, R. D. F. D., L. C. D. Almeida, D. R. D. Souza, C. B. Munhae, O. C. Bueno and M. S. D. C. Morini. 2012. Ant diversity (Hymenoptera: Formicidae) and predation by ants on the different stages of the sugarcane borer life cycle Diatraea saccharalis (Lepidoptera: Crambidae). European Journal of Entomology, 109: 381-87. https://doi.org/10.14411/eje.2012.049

Peeters, C. and B. L. Fisher. 2016. Gamergates (Mated Egg-Laying Workers) and Queens both Reproduce inEuponera sikoraeAnts from Madagascar. African Entomology, 24: 180-87. https://doi.org/10.4001/003.024.0180

Raderschall, C. A., A. Narendra and J. Zeil. 2016. Head roll stabilisation in the nocturnal bull antMyrmecia pyriformis: implications for visual navigation. The Journal of Experimental Biology, 219: 144957.

https://doi.org/10.1242/jeb.134049

Reid, S. F., A. Narendra, R. W. Taylor and J. Zeil. 2013. Foraging ecology of the night-active bull ant Myrmecia pyriformis. Australian Journal of Zoology, 61: 170. https://doi.org/10.1071/zo13027

Ridwansyah, M., T. C. Sunarti and A. M. Fauzi. 2007. Karakteristik sifat fisiko-kimia pati kelapa sawit. Journal of Agroindustrial Technology, 17.

Ronque, M. U. V., V. Fourcassié and P. S. Oliveira. 2018. Ecology and field biology of two dominant Camponotus ants (Hymenoptera: Formicidae) in the Brazilian savannah. Journal of Natural History, 52: 237-52. 
https://doi.org/10.1080/00222933.2017.1420 $\underline{833}$

Shibata, M., M. Varman, Y. Tono, H. Miyafuji and S. Saka. 2008. Characterization in Chemical Composition of the Oil Palm (Elaeis guineensis). Journal of the Japan Institute of Energy, 87: 383-88. https://doi.org/10.3775/jie.87.383

Sorvari, J., M.-K. Haatanen and S.-R. J. J. o. I. C. Vesterlund. 2011. Combined effects of overwintering temperature and habitat degradation on the survival of boreal wood ant, 15: 727-31. https://doi.org/10.1007/s10841-010-9372-5

Tiede, Y., J. Schlautmann, D. A. Donoso, C. I. B. Wallis, J. Bendix, R. Brandl and N. Farwig. 2017. Ants as indicators of environmental change and ecosystem processes. Ecological Indicators, 83: 527-37. https://doi.org/10.1016/i.ecolind.2017.01.029

Wang, C., J. S. Strazanac and L. Butler. 2001. Association Between Ants (Hymenoptera: Formicidae) and
Habitat Characteristics in Oak-Dominated Mixed Forests. Environmental Entomology, 30: 842-48. https://doi.org/10.1603/0046-225x-30.5.842

Widihastuty, M. C. Tobing, Marheni and R. A. Kuswardani. 2018. Prey preference of Myopopone castanea (hymenoptera: formicidae) toward larvae Oryctes rhinoceros Linn (Coleoptera: Scarabidae). IOP Conference Series: Earth and Environmental Science, 122: 012120. https://doi.org/10.1088/17551315/122/1/012120

Wilson, E. O. 1971. The Insect Societies The Belknap Press of Harvard University Press: Cambridge, Massachusetts. London.

Yamazaki, K. 2010. Parachuting Behavior and Predation by Ants in the Nettle Caterpillar, Scopelodescontracta. Journal of Insect Science, 10: $1-10$. https://doi.org/10.1673/031.010.3901

Publisher's note: ESci Journals Publishing remains neutral with regard to jurisdictional claims in published maps and institutional affiliations.

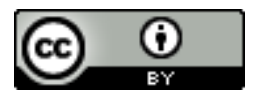

Open Access This article is licensed under a Creative Commons Attribution 4.0 International License, which permits use, sharing, adaptation, distribution and reproduction in any medium or format, as long as you give appropriate credit to the original author(s) and the source, provide a link to the Creative Commons license and indicate if changes were made. The images or other third-party material in this article are included in the article's Creative Commons license, unless indicated otherwise in a credit line to the material. If material is not included in the article's Creative Commons license and your intended use is not permitted by statutory regulation or exceeds the permitted use, you will need to obtain permission directly from the copyright holder. To view a copy of this license, visit http://creativecommons.org/licenses/by/4.0/.

(C) The Author(s) 2019. 